\title{
Inhibition of Drug-Sensitive and Drug-Resistant Mycobacterium Tuberculosis Strains by Essential Oil from Croton Argyrophylloides Mull. Arg.

José Antonio Barreto Alves ${ }^{1}$, Mariangela da Silva Nunes ${ }^{1}$, Ricardo Fakhouri', Paulo Ricardo Saquete Martins-Filho ${ }^{1}$, Maria do Carmo de Oliveira Ribeiro', Alberto Correa de Vasconcellos ${ }^{1}$, Patricia Oliveira Santos ${ }^{1}$, Murilo Marchioro ${ }^{1}$, Rita de Cassia Trindade ${ }^{1}$, Gladslene Goes Santos Frazão , Andreia Centenaro Vaez ${ }^{1}$, KarineVaccaro Tako

\section{Abstract}

Objective: To assess in vitro effects of essential oil extracted from Croton argyrophylloides against clinical and standard strains of Mycobacterium tuberculosis, comparing its resistance and sensitivity profiles to drugs commonly used in therapy.

Method: In the present study, chemical composition and antimycobacterial activity of essential oils extracted from aerial parts of Croton argyrophylloides collected in Curituba district, Sergipe, Brazil were analysed. The oil was studied by GC and GC-MS and its antimicobacterial activity (MIC) was tested against 49 clinical and standard covers $\mathrm{H}_{37} \mathrm{Rv}$ using the REMA method. To access sensitivity to isoniazid, rifampicin, ethambutol and streptomycin it was used proportions indirect test method.

Results: Twenty-seven chemicals were identified, totalizing 95.98\% of the composition of essential oil. The oil presented good antibacterial activity (MIC = 97 to $195 \mathrm{~g} / \mathrm{ml}$ ) against strains of Mycobacterium tuberculosis $\mathrm{H}_{37} \mathrm{Rv}$ and pattern one.

Conclusion: On pharmacological activities of these species confirmed in vitro scientific support for its use in traditional herbal preparations.
1 Federal University of Sergipe, Aracaju, Sergipe, Brazil.

Contact information:

Jose Antonio Barreto Alves.

Address: Department of Nursing, Federal University of Sergipe, Sergipe, Brazil.

Đantoniobalves@gmail.com 


\section{Introduction}

Mycobacteria spp. have increased their virulence and tuberculosis (TB) has become the most lethal infection in the world nowadays. Between 1980 and 2005,90 million cases of TB worldwide were reported to the World Health Organization (WHO). One of the biggest problems about treatment and controlling of TB infection is changes in strains behavior against several drugs due to anti-TB drugs resistance induced by HIV epidemy [1].

In Brazil, many communities use medicinal plants as alternative treatment of infectious diseases, including tuberculosis [2]. Cruz [3] conducted an ethnobotanical study in Curituba village (SergipeBrazil), about medicinal plants used for dermatophytosis, tuberculosis and others, including Croton argyrophylloides Mull. Arg., locally known as "sacatinga".

Croton gender is one of the largest in Euphorbiaceae family, ranging about 800 species. Brazil has registered about 300 species. Widely distributed in northeast of Brazil, especially in sandy ground, Croton spp. is used in many diseases treatments among people living in these areas [2, 4].

This study aims to assess in vitro effects of essential oil extracted from Croton argyrophylloides against clinical and standard strains of Mycobacterium tuberculosis, comparing its resistance and sensitivity profiles to drugs commonly used in therapy.

\section{Methods}

\section{Plant material}

Plant selection was based on ethnobotanical study of popular uses of medicinal plants conducted by Cruz [3]. Botanical material was collected on November, 11 ${ }^{\text {th }}, 2009$, georeferenced as (S 09³9'40.0", W 037055'16.3"; Altitude: 205 meters). Plant material was collected, than evaluated and identified by Ms. Gilvane Viana Souza (Botanical Department of Federal University of Sergipe, UFS).
A voucher specimen selected plant was deposited at the Herbarium ASE under the register number: ASE 13161.

\section{Essential oil}

The essential oil was obtained by hydrodistillation (for 3 h) of C. argyrophyloides fresh leaves in a Clevenger-type apparatus, until no more condensing oil could be seen. The essential oil was separated from the aqueous solution (hydrolate), dried with anhydrous $\mathrm{Na} 2 \mathrm{SO} 4$ (yield 0.5\% v/w), transferred to an amber glass flask, and kept at temperature of $14^{\circ} \mathrm{F}\left(-10^{\circ} \mathrm{C}\right)$ until used.

\section{Gas chromatography - mass spectrometry (GC-MSms)}

Oil sample analysis was performed on a Shimadzu QP5050A gas chromatograph (Shimadzu Corporation, Kyoto, Japan), interfaced to a mass spectrometer (GC-MS). The following conditions were used: DB5 column (30 cm x $0.25 \mathrm{~mm}$ i.d., 5\% phenylmethylpolysiloxane); helium (99.999\%) carrier gas at a constant flow of $1.2 \mathrm{~mL} \mathrm{~min}^{-1} ; 0.5$ $\mu \mathrm{L}$ injection volume (in ethyl acetate); injector split ratio of 1:20; injector temperature $250^{\circ} \mathrm{C}$; electron impact mode at $70 \mathrm{eV}$; ion-source temperature $280{ }^{\circ} \mathrm{C}$. The oven temperature was programmed from $80^{\circ} \mathrm{C}$ (isothermal for $2 \mathrm{~min}$ ), with an increase of $3{ }^{\circ} \mathrm{C} \mathrm{min}-1$ to $180{ }^{\circ} \mathrm{C}$, then $10{ }^{\circ} \mathrm{C} \mathrm{min}-1$ to 300 ${ }^{\circ} \mathrm{C}$, and $10 \mathrm{~min}$ isothermal at $300^{\circ} \mathrm{C}$. Mass spectra were taken at $70 \mathrm{eV}$, with a scan interval of 0.5 $S$, and considered ion fragments in the range 40 to $450 \mathrm{Da}$.

A mixture of linear hydrocarbons $\left(\mathrm{C}_{9} \mathrm{H}_{20}-\mathrm{C}_{19} \mathrm{H}_{40}\right)$ was injected under the same conditions as samples, and identification of constituents performed by comparing the spectra obtained with those of the equipment's database (NIST 21 and NIST 107), and by using Kovats Index, calculated for each constituent as previously described [5]. 


\section{Microorganisms}

Forty-nine clinical strains of $M$. tuberculosis and standard strain $\mathrm{H}_{37} \mathrm{RV}$ were tested. These strains were part of culture collections from Central Laboratory of Sergipe and Applied Microbiology Laboratory, Federal University of Sergipe.

\section{Sensitivity and resistance profile of M. tuberculosis strains: the proportion method procedure}

The proportion method was performed as described by National Committee for Clinical Laboratory Standards (NCCLS 2002). Antimycobacterial drugs were adjusted in the LJ medium to final concentrations of $0.2-1 \mu \mathrm{g} / \mathrm{mL}$ for isoniazid (INH), $40 \mu \mathrm{g} / \mathrm{mL}$ for rifampicin (RIF), $4 \mu \mathrm{g} / \mathrm{mL}$ for streptomycin (STR), and $2 \mu \mathrm{g} / \mathrm{mL}$ for ethambutol (ETM). One hundred microliter of prepared bacterial inoculum was inoculated on LJ medium, containing or not drug for test or as a control, followed by incubation at $37^{\circ} \mathrm{C}$ for 21-28 days. Resistance was defined as growth on drug containing tubes greater than $1 \%$ of the growth of drug free control medium for INH, RIF, ETM, and $10 \%$ for STR $[6,7]$.

\section{Antimycobacterial activity of essential oil}

The method used for antimycobacterial activity determination was [8]. The screening assay was, in brief, accomplished in microplates (96 wells) using resazurin as indicator of cellular viability. The concentrations for essential oil ranged from $125.000 \mu \mathrm{g} /$ $\mathrm{mL}$ até $97 \mu \mathrm{g} / \mathrm{mL}$. Briefly, to prepare inoculums, bacterial suspension adjusted to equal the density of a 1.0 McFarland standard was diluted 1:25 in medium $7 \mathrm{H} 9$ enriched with 10\% OADC. To each well was added $100 \mu \mathrm{l}$ of inoculums and $100 \mu \mathrm{l}$ concentrations for essential oil. The plates were sealed, placed in plastic bags and incubated at $37^{\circ} \mathrm{C}$ for seven days in normal atmosphere. After seven days of incubation, $30 \mu$ l of resazurin solution was added to each well, incubated at $37^{\circ} \mathrm{C}$, and assumed for color development. A change from blue to pink in- dicates reductions of resazurin and therefore bacterial growth. The MIC was defined as the lowest essential oil concentration that prevented this color change.

\section{Results}

Chemical compounds identified, their percentages and retention indices of C. argyrophylloides Mull. Arg. essential oil are listed in Table 01. Out of 30 compounds found, 27 were identified by gas chromatography, which confirmed a high content of terpenes. It was found a major percentage of metabolites classified as monoterpenes (48.22\%) and sesquiterpenes (47.76\%). The major monoterpenes were: myrcene $7.92 \%$, $\alpha$-pinene $7.15 \%$, the $\beta$-phellandrene $5.43 \%, 1,8$-cineole $5.23 \%$ and $\delta$-3Carene $4.27 \%$.

About sesquiterpenes, Bicyclogermacrene showed the highest concentration totalizing 12.99\% of all chemicals identified, followed by spathulenol (11.33\%) and $\beta$-caryophyllene (9.76\%).

Three metabolites of essential oil were detected by mass spectrometry, but were not identified by gas chromatography, corresponding to $5.57 \%$ of chemical composition of the sample. (Table 1)

The essential oil of C. argyrophylloides was tested against 49 clinical strains and one standard strain $\left(\mathrm{H}_{37} \mathrm{Rv}\right)$. Nineteen clinical strains belonged to Bank of Strains of Applied Microbiology Laboratory, Federal University of Sergipe (AML / UFS) and 30 clinical strains and the standard strain belonged to the Central Laboratory of Sergipe.

Results obtained in tests of Minimum Inhibitory Concentration-MIC with C. argyrophylloides Mull. Arg. essential oil and susceptibility profile of $M$. tuberculosis strains against rifampicin (RIF), isoniazid (INH), ethambutol (ETM) and streptomycin (STR) are shown in Table 2

Minimum inhibitory concentrations of essential oil tested by REMA method standardized by Palomino [8] ranged between 97 and $195 \mu \mathrm{g} / \mathrm{mL}$ for clinical 
Table 1. Essential oil composition (\%) of Croton argyrophylloides Mull. Arg.

\begin{tabular}{|c|c|c|c|c|c|}
\hline Peak & RT (min) & Compound & $(\%)$ & RRI exp. ${ }^{a}$ & RRI lit. b \\
\hline 1 & 6.583 & $\alpha$-Thujeno & 2.35 & 917 & 924 \\
\hline 2 & 6.808 & $\alpha$-Pineno & 7.15 & 925 & 932 \\
\hline 3 & 8.058 & Sabineno & 2.47 & 968 & 969 \\
\hline 4 & 8.217 & $\beta$-Pineno & 3.18 & 974 & 974 \\
\hline 5 & 8.608 & Mirceno & 7.92 & 988 & 988 \\
\hline 6 & 9.258 & 8-3-Careno & 4.27 & 1008 & 1008 \\
\hline 7 & 9.833 & $\mathrm{p}$-Cimeno & 0.49 & 1024 & 1020 \\
\hline 8 & 9.992 & Limoneno & 2.30 & 1029 & 1024 \\
\hline 9 & 10.050 & $\beta$-Felandreno & 5.43 & 1030 & 1025 \\
\hline 10 & 10.108 & 1,8-Cineol & 5.23 & 1032 & 1026 \\
\hline 11 & 10.625 & (E) $\beta$-Ocimeno & 0.85 & 1046 & 1044 \\
\hline 12 & 11.042 & ү-Terpineno & 0.64 & 1058 & 1054 \\
\hline 13 & 12.017 & Terpinoleno & 1.10 & 1085 & 1086 \\
\hline 14 & 12.583 & Linalol & 1.81 & 1100 & 1095 \\
\hline 15 & 15.567 & Terpinen-4-ol & 1.31 & 1181 & 1174 \\
\hline 16 & 16.117 & $\alpha$-Terpineol & 0.85 & 1196 & 1186 \\
\hline 17 & 21.125 & $\delta$-Elemeno & 0.65 & 1335 & 1335 \\
\hline 18 & 21.533 & $\begin{array}{l}\text { Acetato de } \\
\alpha \text {-Terpineno }\end{array}$ & 0.22 & 1347 & 1346 \\
\hline 19 & 23.000 & $\beta$-Elemeno & 4.05 & 1390 & 1389 \\
\hline 20 & 24.017 & $\beta$-Cariofileno & 9.76 & 1420 & 1417 \\
\hline 21 & 25.208 & $\alpha$-Humuleno & 1.53 & 1456 & 1452 \\
\hline 22 & 26.508 & Biciclogermacreno & 12.99 & 1496 & 1500 \\
\hline 23 & 26.900 & Germacreno A & 0.93 & 1508 & 1508 \\
\hline 24 & 27.958 & $\alpha$-Calacoreno & 0.58 & 1542 & 1544 \\
\hline 25 & 28.517 & Germacreno B & 2.77 & 1560 & 1559 \\
\hline 26 & 28.617 & Não identificado & 4.97 & 1563 & - \\
\hline 27 & 29.075 & Spathulenol & 11.33 & 1578 & 1577 \\
\hline 28 & 29.250 & $\begin{array}{l}\text { Óxido de } \\
\text { Cariofileno }\end{array}$ & 2.30 & 1584 & 1582 \\
\hline 29 & 29.942 & Não identificado & 0.11 & 1606 & - \\
\hline 30 & 30.217 & Não identificado & 0.49 & 1615 & - \\
\hline
\end{tabular}

a: $R R I=$ relative retention index using the Van den Dool equation. 1963 [9]. b. According to Adams, 1995 [5].
Table 2. MIC ( $\mu \mathrm{g} / \mathrm{mL})$ of essential oil from C. argyrophylloides Mull. Arg. and sensibility profile of $M$. tuberculosis strains to anti-TB drugs

\begin{tabular}{|c|c|c|c|c|c|}
\hline Strains & $\begin{array}{c}\text { MIC }^{a} \text { of } \\
\text { essential } \\
\text { oil }(\mu \mathrm{g} / \mathrm{mL})\end{array}$ & RIF $^{b}$ & INHC $^{C}$ & ETM $^{d}$ & $\mathrm{STR}^{\mathrm{e}}$ \\
\hline HRV37 & 97 & $S$ & $S$ & $S$ & $S$ \\
\hline $\begin{array}{l}\text { 13; } 21 ; 34 ; 37 ; 43 ; 133 ; \\
\text { 594; 723; 825; 846; } \\
\text { 869;870; 889; 1047; } \\
\text { 1135; 1145; 1290; } \\
\text { 1307; 1328; 1374; } \\
\text { 050; 770; 2580; 2910; } \\
\text { 4840; 4930; 5020; } \\
\text { 5550; 6870; 7700; } \\
\text { 8510; 9110; 9210; } \\
\text { 10810; 12090; 12930; } \\
\text { 14050;14880; } 15060\end{array}$ & 97 & $S$ & $S$ & $S$ & $S$ \\
\hline 658 & 195 & $\mathrm{R}$ & $\mathrm{R}$ & $\mathrm{R}$ & $S$ \\
\hline 725; 1317 & 195 & $S$ & $\mathrm{R}$ & $\mathrm{R}$ & $S$ \\
\hline $\begin{array}{l}810 ; 909 ; 948 ; 1322 ; \\
1343\end{array}$ & 97 & $S$ & $S$ & $S$ & $\mathrm{R}$ \\
\hline 1057 & 195 & $S$ & $\mathrm{R}$ & $S$ & $S$ \\
\hline 1224 & 195 & $\mathrm{R}$ & $\mathrm{R}$ & $S$ & $S$ \\
\hline
\end{tabular}

strains. Only five strains showed MIC equal to 195 $\mu \mathrm{g} / \mathrm{mL}$. All other strains including standard strain $\left(\mathrm{H}_{37} \mathrm{Rv}\right)$ had MIC of $97 \mu \mathrm{g} / \mathrm{mL}$.

Results of $M$. tuberculosis susceptibility analysis from gold standard chemotherapy recommended by Health Ministry showed that out of 49 strains tested, 10 were resistant to one chemotherapic at least. Strains resistant to anti-tuberculosis drugs revealed a prevalence of $20 \%$ (Table 2 ).

Correlation between strains resistant to anti-tuberculosis drugs and MIC values found for essential oil tested showed that four clinical strains which were resistant to more than one of the antibiotics tested, and two clinical strains which were considered multiresistant showed MIC values for C. argyrophylloides Mull. Arg. essential oil equal to 195 $\mu \mathrm{g} / \mathrm{mL}$. Additionally, in all strains that showed resistance to RIF, INH and/or ETM, MIC values for $C$. 
argyrophylloides Mull. Arg. essential oil was equal to $195 \mu \mathrm{g} / \mathrm{mL}$. In all strains resistant to STR, MIC values for C. argyrophylloides Mull. Arg. essential oil was equal to $97 \mu \mathrm{g} / \mathrm{mL}$.

\section{Discussion}

Use of medicinal plants in curing TB-related symptoms is reported, especially, in South American and African regions, where health services access is precarious and TB rates are more significant among people living under low social and economical conditions. Researches for new anti-TB drugs include screening bioactive compounds of vegetable sources $[1,10]$. Thus, testing C. argyrophylloides Mull. Arg. essential oil against clinical and standard strains of $M$. tuberculosis, which tuberculosis treatment regimen drugs sensitivity profile has shown resistance or multiresistance, was useful.

Most antibiotics used in experiments of this study are part of Schedule I to treat tuberculosis [11]. In isolation, Streptomycin and Isoniazid were less effective, both presenting five strains resistant. Studies $[12,13,14,15,16]$ confirm isoniazid to be less effective against $M$. tuberculosis. By these studies, STR was more effective than INH. Differently, in our data both had the same strains resistance profile. For Ethambutol, three strains were resistant. The most effective antibiotic was Rifampicin, which only two samples of $\mathrm{M}$. tuberculosis were resistant; these strains were concomitantly resistant to rifampin and isoniazid, classifying them as multidrug resistant strains, according to literature [14]. Evaluating this study results, one can observe that there is a change in resistance and multidrug resistance profile to medication regimens used. Thus, research for active and less toxic substances against mycobacteria has motivated to find solutions for tuberculosis treatment since ancient times [17].

C. argyrophylloides Mull. Arg. tradicionally is traditionally used by district of Curituba communities, in Sergipe, Brazil, for TB-related symptoms treatment. Some species of Croton gender, C. pseudopulchellus and C. sylvaticus, have already confirmed their antimycobacterial activity $[9,18]$. These studies corroborate popular knowledge of its use in TB-therapy and demonstrate the importance of this kind of drug discovery [19, 20, 21, 22, 23, 24].

Our data has shown that all 49 clinical strains and standard $\mathrm{H}_{37} \mathrm{Rv} M$. tuberculosis tested were sensitivity to essential oil extracted from fresh leaves of C. argyrophylloides Mull. Arg. with MIC values equal to $97 \mu \mathrm{g} / \mathrm{mL}$ (45 strains) and $195 \mu \mathrm{g} / \mathrm{mL}$ (05 strains). Noteworthy, all strains sensitive to antibiotics tested showed sensitivity to the essential oil at concentration of $97 \mu \mathrm{g} / \mathrm{mL}$; in contrast, five strains that showed sensitivity at higher concentration (195 $\mu \mathrm{g} / \mathrm{mL}$ ), were resistant to isoniazid. The low MIC values of essential oil of C. argyrophylloides Mull. Arg. can be considered promising when compared to MIC values found by some authors, as compared to other products derived from plants. Allied to this fact, it is important to remember that most researches are carried out exclusively with standard strains, without clinical strains as we did, frequently subjected to constant change and therefore more resistant.

Study [25] tested extracts from five plants (Marrubium vulgare, Mentha spicata, Artemisia ludoviciana, Chaenopodium ambrosioides and Flourens cernua), compared to $M$. tuberculosis standard strains and found MIC values equal to $400 \mu \mathrm{g} / \mathrm{mL}$. Study [26] found antimycobacterial action in ten plants from South Africa; some of these plants has action set at $195 \mu \mathrm{g} / \mathrm{mL}$.

In Mexico, several studies have demonstrated potential of regional plants against $M$. tuberculosis in vitro. Extract taken from Buddleja cordata is active at concentration of $64 \mu \mathrm{g} / \mathrm{mL}[28,29]$ uses extracts from 48 plants originated in South America to standard strains $\mathrm{H}_{37} \mathrm{Rv}$ and only seven from them shows action at concentration of $100 \mu \mathrm{g} / \mathrm{mL}$.

MICs values found in this study may be associated to the interaction of oil with $\mathrm{M}$. tuberculosis cell 
wall, since it is rich in high molecular weight lipid, facilitating the contact with nonpolar substances [30].

Mono and sesquiterpenes percentage we found were similar to those reported by [4, 20], when identifying chemical compounds of $C$. argyrophyIloides Mull. Arg. essential oil collected in Viçosa, Ceará, Northeastern Brazil. Differences in percentage composition of essential oil can exist and are due to temperature and season of the region where he collected the plant material, location, storage, methods of oil extraction and others. However, presence of these substances in relevant different percentage can mean genetic inheritance of the [31].

In spite of previous studies of C. argyrophylloides Mull Arg. essential oil performance, the need for checking chemical composition is justified, once his action is related to existing concentration of each substance and possibly with the synergistic action of them [32].

Despite antimycobacterial potential in vitro of $C$. argyrophylloides Mull Arg. essential oil evidenced by MICs values, it is important that studies on mechanisms of action and activity in vivo are carried out to confirm its effectiveness in treating the symptoms of $\mathrm{TB}$.

\section{References}

1. World Health Organisation, 2008. Implementing the stop TB strategy: A handbook for national tuberculosis control programmes. Genova, (WHO/HTM/TB/2008.401).

2. Duarte MCT, Figueira GM, Sartoratto A, Rehder VLG, Delarmelina C. Anti-Candida activity of Brazilian medicinal plants. J Ethnopharmacol. 2005;97:305-311.

3. Cruz MCS, 2002. Avaliação da atividade antifúngica de plantas utilizadas popularmente pela comunidade de Curituba, Município de Canindé do São Franciasco - SE. Sergipe, 139 p. Dissertação de Mestrado, Programa de Pós Graduação em Desenvolvimento e Meio Ambiente, Universidade Federal de Sergipe.

4. Fontenelle ROS, Morais SM, Brito EHS, Brilhante RSN, Cordeiro RA, Nascimento NRF, et al. Antifungal activity of essential oils of Cronton species from the Brazilian Caatinga biome. J Appl Microbiol. , 2008;104:1383-1390.
5. Adams RP 1995. Identification of essential oil components by gas chromatography/ mass spectroscopy. Illinois: Allured Publishing Corporation.

6. Leite CQF, Beretta ALRZ, Anno IS, Telles MAS. Standartization of broth microdilution method for Mycobacterium tuberculosis. Mem Inst Osw Cruz. 2000;95:127-129.

7. National Committee for Clinical Laboratory Standards 2002. Antimycobacterial susceptibility testing for Mycobacterium tuberculosis. Tentative standard M24-T, NCCLS: Villanova. P.A.

8. Palomino JC, Martin A, Camacho M, Guerra H, Swings J, Portaels F. Resazurin Microtiter Assay Plate: Simple and inexpensive method for detection of drug resistance in Mycobacterium tuberculosis. Antimicrob Agents Chemother. , 2002;46:27202722.

9. Van den Dool H, Kratz PD. J Chromatograph. 1063;11:463.

10. Lall N, Das Sarma M, Hazra B, Meyer JJM. Antimycobacterial activity of diospyrin derivatives and a structural analogue of diospyrin against Mycobacterium tuberculosis in vitro. J Antimicrob Agents Chemoth. 1999;51:435-438.

11. BRASIL. Ministério da Saúde/ SVS. Programas Estratégicos. Disponível em: <http://portal.saude.gov.br/portal/aplicacoes/ busca/buscar.cfm> acesso em : 17 maio 2016.

12. Ribeiro OM, Gomes MS, Senna SG, Rosseti MLR, Fonseca LS. Avaliação de testes rápidos em microplacas usando indicadores de viabilidade celular para determinação da susceptibilidade de cepas de Mycobacterium tuberculosis à isoniazida e rifampicina. J Bras Pneumol. 2004;30:455-460.

13. Mengato L, Chiani Y, Imaz MS. Evaluation of rapid methods for drug susceptibility testing in clinical isolates of Mycobacterium tuberculosis. Mem Inst Osw Cruz. 2006;101:535-542.

14. Rozman LM, Santos AH, Rozman-Mauro A. Resistência do Mycobacterium tuberculosis às drogas em pacientes HIV+ em cinco municípios da Baixada Santista, São Paulo, Brasil. Cad Saúde Pública.2007; 23:1051-1059.

15. Nunes EA, Capitani EM, Coelho E, Panunto AC, Joaquim OA, Ramos MC. Doença pulmonar por Mycobacterium tuberculosis e micobacterias não-tuberculasas entre pacientes recémdiagnosticados como HIV positivo em Moçambique, África. J Bras Pneumol. 2008;34:822-828.

16. Miranda SS, Toledo ARP, Ribeiro SR, Campos IM, Sthur PMOD, Kritski AL. Incidência de TB diagnosticada no prontoatendimento de um hospital escola na região sudeste do Brasil. J Bras Pneumol. 2009;35:174-178.

17. Gautam R, Saklani A, Jachak SM. Indian medicinal plants as a source of antimycobacterial agents. J Ethnopharmacology. 2007;110:200-234.

18. Bamuamba K, Gammon DW, Meyers P, Dijoux-Franca MG, Scott G. Anti-mycobacterial activity of five plant species used as traditional medicines in the Western Cape Province (South Africa). J Ethnopharmacol. 2008;117:385-390. 
19. Barreto-Jr AG, Biscaia-Jr EC, Veiga-Jr VF, Pinto AC, Carvalho SF, Maciel MA. Cromatografia de troca-iônica aplica ao isolamento da fração ácidado óleo de Copaíba (Copaiba multijuga) e da Sacaca (Croton cajucara). Quím. Nova. 2005;28:719-722.

20. Morais SM, Cavalcanti ESB, Bertini LM, Oliveira CLL, Rodrigues JRB, Cardoso JHL. Larvicidal activity of essential oils from Brazilian Croton species against Aedes aegypti L. J Americ Mosq Control Association. 2006;22:161-164.

21. Radulovic N, Stojanovic G, Palic R. Composition and antimicrobial activity of Equisetum arvense L. essential oil. Phytother Research. 2006;20:85-88

22. Costa JGM, Rodrigues FFG, Angelico EC, Pereira CKB, Souza EO, Caldas GFR et al. Composição química e avaliação da atividade antibacteriana e toxicidade do óleo essencial de Croton zehneri (variedade estragol). Rev Brasil Farmacog. 2008;18:583-586.

23. Rocha FF, Neves EMN, Costa EA, Matos LG, Adolfo HM, Guilhon GMSP et al. Evaluation of antinociceptive and antiinflammatoyu effects os Croton pullei var. glabrior Larnj. (EUPHORBIACEAE). Rev Bras Farmacog. 2008;18:344-349.

24. Santos PO, Costa MJC, Alves JAB, Nascimento PFC, Melo DLFM, Barbosa-Jr AM. Chemical composition and antimicrobial activity of the essential oil of Hyptis pesctinata (L.) poit. Quím Nova. 2008;31:1648-1652

25. Molina-Salinas GM, Ramos-Guerra MC, Vargas-Villareal J, MataCardenas BD, Becerril-Montes P, Said-Fernandez S. Bactericidal activity of organic extract from Flourensia cernua DC against strain of Mycobacterium tuberculsosi. Arch Med Research. 2006;37:45-49.

26. Eldeen IMS, Staden JV. Antimycobacterial activity of some trees used in South African tradicional medicine. South African J Botany. 2007;73:248-251.

27. Acevedo L, Martínez E, Castañeda P, Franzblau S, Timmermann BN, Linares E. New Phenylethanoids from Buddleja cordata subsp. cordata. Planta Med. 2000; 66: 257-261.
28. Leitão SG, Castro O, Fonseca EN, Julião LS, Tavares ES, Leo RRT. Screening of central and South American plant extracts for antimycobacterial activity by the Alamar Blue test. Rev Bras Farmacog. 2006;16:06-11.

29. Ducati RG, Ruffino-Neto A, Basso LA, Santos DS. The resumption of consuption - A review on tuberculosis. Mem Inst Osw Cuz. 2006;107:697-714.

30. Gobo-Neto L, Lopes NP. Plantas medicinais: fatores de influência no conteúdo de metabólitos secundários. Qui Nova. 2007; 30:374-381

31. Bakkali FS, Averbeck D, Averbeck M. Biological effects of essential oils - A review. Food Chem Toxicol. 2008;46:S446475.

\section{Publish in International Archives of Medicine}

International Archives of Medicine is an open access journal publishing articles encompassing all aspects of medical science and clinical practice. IAM is considered a megajournal with independent sections on all areas of medicine. IAM is a really international journal with authors and board members from all around the world. The journal is widely indexed and classified Q1 in category Medicine. 